\title{
Water economy of three Cinclodes (Furnariidae) species inhabiting marine and freshwater ecosystems
}

\author{
Economía hídrica en tres especies de Cinclodes (Furnariidae) \\ que habitan ecosistemas marinos y de agua dulce \\ PABLO SABAT ${ }^{1,2^{*}}$, ROBERTO F. NESPOLO ${ }^{2,3}$ \& FRANCISCO BOZINOVIC ${ }^{2}$ \\ ${ }^{1}$ Departamento de Ciencias Ecológicas Facultad de Ciencias, Universidad de Chile, \\ Casilla 653, Santiago, Chile 6513677; e-mail: psabat@uchile.cl \\ ${ }^{2}$ Center for Advanced Studies in Ecology \& Biodiversity and Departamento de Ecología, \\ Facultad de Ciencias Biológicas, Pontificia Universidad Católica de Chile, Santiago, Chile 6513677 \\ ${ }^{3}$ Instituto de Ecología y Evolución, Facultad de Ciencias, Universidad Austral de Chile, \\ Campus Isla Teja Casilla 567, Valdivia, Chile 6513677 \\ * To whom correspondence should be addressed
}

\begin{abstract}
Birds living in desert environments have been the preferred models for the study of physiological adaptations to water scarcity. Passerine birds living in marine coastal habitats face similar problems, yet physiological adaptations to water conservation in such species have been poorly documented. We measured total evaporative water loss (TEWL) and rates of oxygen consumption $\left(\mathrm{VO}_{2}\right)$ in three species of passerine birds dwelling in marine and fresh water habitats. Mass specific total evaporative water loss was significantly lower in the marine species, Cinclodes nigrofumosus, than in species inhabiting areas near freshwater sources. We found a positive relationship between TEWL and $\mathrm{VO}_{2}$. The ratio of TEWL to $\mathrm{VO}_{2}$ (relative evaporative water loss, RTEWL) showed significant variation among Cinclodes species, and was highest for the fresh-water living species, C. oustaleti and C. fuscus. The variation in TEWL found in Cinclodes is likely a consequence of differential exploitation of marine prey with high osmotic loads, which, in turn, may impose the need for water conservation.
\end{abstract}

Key words: evaporative water loss, Cinclodes, osmoregulation, passerines, salt.

\section{RESUMEN}

Las aves que habitan ambientes desérticos han sido modelos de estudio preferidos para el estudio de adaptaciones fisiológicas a la escasez de agua. Las aves paseriformes que habitan hábitat costeros enfrentan problemas similares, aunque las posibles adaptaciones fisiológicas para la conservación de agua en dichas especies han sido pobremente documentadas. En este estudio se determinó la pérdida total de agua por evaporación (TEWL) y la tasa de consumo de oxígeno $\left(\mathrm{VO}_{2}\right)$ en tres especies de aves paseriformes que habitan ambientes marinos y de agua dulce. La pérdida total de agua por evaporación masa-específica fue significativamente menor en la especie marina, Cinclodes nigrofumosus, que en especies que habitan áreas cercanas a fuentes de agua dulce. Se encontró una relación positiva y significativa entre TEWL y $\mathrm{VO}_{2}$. La razón entre TEWL y el $\mathrm{VO}_{2}$ (pérdida relativa de agua por evaporación, RTEWL) presentó una variación significativa entre las especies de Cinclodes, siendo mayor para las especies de agua dulce C. oustaleti y $C$. fuscus. La variación en TEWL encontrada en Cinclodes es probablemente una consecuencia de la explotación diferencial de presas marinas con una alta carga osmótica, lo que a su vez puede imponer la necesidad de conservación de agua.

Palabras clave: Cinclodes, osmorregulación, paseriformes, pérdida de agua por evaporación, sal.

\section{INTRODUCTION}

Adaptations of birds to life in deserts may include different combinations of cellular, physiological, behavioral, and ecological features (Braun 1978, Tieleman et al. 1999, Tieleman et al. 2002, Haugen et al. 2003).
Indeed, physiological traits such as comparatively low total evaporative water loss (TEWL) permit desert birds to cope with desert conditions, by allowing more efficient water conservation (Dawson 1982, Williams 1996, McNab 2002, Tieleman et al. 2003, and references therein). Marine birds are challenged 
with similar conditions due to the high osmotic stress associated with the consumption of seawater and salt-loaded prey. In order to deal with the extra salt load associated with drinking seawater, birds with salt glands produce hyperosmotic fluids (Holmes \& Phillips 1985). Nevertheless, there are some passerines that lack salt glands, and yet inhabit intertidal habitats and consume hyperosmotic prey. How these birds cope with the salt load from the fluids of their marine prey is puzzling (Poulson \& Bartholomew 1962, Goldstein et al. 1990, Sabat \& Martínez del Río 2002). Indeed, only a few species of passerines have colonized coastal environments. Among them, the genus Cinclodes (Furnariidae) includes species that relay mainly on invertebrate salty prey from the marine coast (Sabat \& Martínez del Río 2002, Sabat et al. 2003). Although all Cinclodes species inhabit land-water interfaces (e.g., streams, meadows, beaches), in Chile there is considerable interspecific and intraspecific variation in the use of intertidal habitats (Sabat 2000, Sabat \& Martínez del Río 2002). The genus Cinclodes offers opportunities for investigating physiological diversity related to the energy and water economy of birds, and for examining their ecological consequences. The species Cinclodes nigrofumosus is marine dwelling, foraging and reproducing exclusively at marine coastal habitats (Stotz et al. 1996), whereas the species $C$. oustaleti and $C$. fuscus seasonally migrate from freshwater to marine ecosystems (Sielfeld et al. 1996, Jorge et al. 1998). These latter two species inhabit the intertidal system exclusively during the austral winter, when rainwater is available and mild temperatures may reduce TEWL (Sielfeld et al. 1996, Jorge et al. 1998, Sabat 2000). During the warm, dry summer these bird species migrate to inland areas near streams and lake shores (Sabat 2000). Sabat \& Martínez del Río (2002) found interspecific differences in renal osmoregulatory capacities of these three Cinclodes species. These authors speculated that such physiological differences may explain the spatial and temporal variability in habitat use, where, in the absence of freshwater, $C$. oustaleti (and probably C. fuscus, as well) are not able to take advantage of the abundant, yet salt-loaded, marine invertebrate prey. In contrast, C. nigrofumosus, which is a yearround resident of intertidal areas, consume saltloaded prey with concentrations as high as 1,000 mOsm $\mathrm{kg}^{-1}$ (Sabat \& Martínez del Río 2002, Sabat et al. 2003).

In this study we evaluated whether passerine species inhabiting the intertidal habitat exhibit similar physiological traits to desert-dwelling birds. These birds that lack salt glands are faced with the problem of water conservation under conditions where the spatial and temporal availability of freshwater is limited or scarce. Thus, we predicted that the marine species (C. nigrofumosus) would exhibit lower TEWL than the two species inhabiting a mixture of marine and freshwater environments, indicating that the marine species has a mechanism for increased water conservation. Classically, studies in comparative ecological physiology emphasize the analysis of species as units. However, studies that include comparisons of physiological traits across species, such as TEWL, may encounter problems in interpretation, since species may differ not only in ecological traits, but also in phylogenetic histories (Tieleman et al. 2002). Although there is an increase in the use of phylogenetically based statistical methods to inferring adaptation (see Garland \& Adolph 1994, Garland et al. 1999), comparative studies of closely related species minimize the effects of potentially confounding variables associated with phylogeny, and may give insight into how differences in organismal physiology evolved. For these reasons, we utilized this approach for studying species within a genus from the same region, but from different habitats. We believe this procedure provides an effective tool for understanding physiological tolerances and their ecological significance.

\section{MATERIAL AND METHODS}

All study animals were collected between December and February, during the warm, dry seasons of 2001 and 2002 (austral summer). Birds were collected using mist nets from two sites in central Chile. Birds were collected with the permission № 1863 of the Servicio Agrícola $y$ Ganadero. Specimens of the strictly marine dwelling species, C. nigrofumosus, were


a coastal area characterized as a mesic system. The partially or seasonally marine species, $C$. oustaleti and $C$. fuscus were collected from El Manzano (333' $\mathrm{S}, 70^{\circ} 22^{\prime} \mathrm{W}$ ), which is an inland freshwater stream habitat in central Chile (1,300 $\mathrm{m}$ of altitude). The two collecting sites are separated by approximately $120 \mathrm{~km}$. We collected a total of eight specimens of $C$. nigrofumosus, five $C$. fuscus and six $C$. oustaleti. Upon the capture of capture birds, they were transported to the laboratory in Santiago 
and housed in individual $50 \times 50 \times 50 \mathrm{~cm}$ plastic cages, and fed mealworms and water ad libitum for two days prior to measurements. We measured rates of oxygen consumption $\left(\mathrm{VO}_{2}\right)$ and total evaporative water loss (TEWL) in post absorptive birds, using dark metabolic chambers. Oxygen consumption was measured in a computerized (Datacan V), open-flow respirometry system (Sable Systems, Henderson, Nevada) which was calibrated monthly with a known mix of oxygen $(20 \%)$ and helium (80\%) certified by chromatography (INDURA, Chile), and the cell was restored every two weeks. Measurements of animals were made in glass metabolic chambers of $1,000 \mathrm{~mL}$, at an ambient temperature $\left(T_{\mathrm{a}}\right)$ of $25.0 \pm 0.5{ }^{\circ} \mathrm{C}$. This temperature was also selected for comparative purposes (see Williams 1996). The metabolic chamber received dried air at a rate of $800 \mathrm{~mL}$ $\mathrm{min}^{-1}$ from mass flow controllers and through tygon tubing (Sierra Instruments, Monterey, California, USA), which was enough to ensure adequate mixing in the chamber. The mass flow meter was calibrated monthly with a volumetric (bubble) flow meter. Air passed through $\mathrm{CO}_{2}-$ absorbent granules of Baralyme and Drierite before and after passing through the chamber, and was monitored every $5 \mathrm{~s}$ by an Applied Electrochemistry $\mathrm{O}_{2}$-analyzer, model S-3A/I (Ametek, Pittsburgh, Pennsylvania, USA). Oxygen consumption values were calculated using equation $4 \mathrm{a}$ of Withers (1977). The complete $\mathrm{VO}_{2}$ trial lasted two hours. We recorded total oxygen consumption over the two last hour trials, and calculated mean oxygen consumption per day for each trial $\left(\mathrm{TVO}_{2}\right)$. Together with $\mathrm{VO}_{2}$ recordings, we gravimetrically measured TEWL (Hainsworth 1968). This was accomplished by passing air through a series of columns of Drierite to remove water before the air entered the massflow controllers. Inside of the chambers birds perched on a wire-mesh grid through which faeces and urine fell into a tray containing mineral oil, thus trapping the water from these sources. Therefore, we were confident that all of the water in the air leaving the chambers reflected TEWL. Birds were supplied with dried air. Chamber water outflow was absorbed with tubes filled with Drierite, which were weighed to the nearest $0.1 \mathrm{mg}$ on an analytical balance, both before and after trials. The drying tubes were replaced every hour with the initiation of each complete cycle of oxygen consumption measurements. The mean water loss $\left(\mathrm{mLday}^{-1}\right)$ was calculated using the last hour of measurements, after the birds reached a steady state in VO2 consumption.

\section{Data analysis}

We used ANOVA to test for interspecific differences in physiological variables. The most appropriate analysis for biological variables with allometry is ANCOVA, using body mass as a covariate. However, this is justified only if the correlation between the physiological variable and body mass is significant, given that ANCOVA reduces degrees of freedom in one (reducing power). Since our Cinclodes species differed in body mass $\left(\mathrm{m}_{\mathrm{b}}\right)$, but there was no significant scaling, we conducted an ANOVA using mass adjusted metabolic and water loss rates (see Tieleman et al. 2002). We divided the total water loss by $\mathrm{m}_{\mathrm{b}}{ }^{0.634}$, where 0.634 is the exponent of an allometric equation relating the TEWL and body mass of 48 species of passerine birds, described by Williams (1996). We compared our results with the expected values from the allometric equations mentioned above. In addition, since TEWL might be related to oxygen consumption, we performed a linear regression analysis using TEWL as the dependent variable and $\mathrm{TVO}_{2}$ as the independent variable. To test for differences in the efficiency of water conservation between species, we calculated the relative of evaporative water loss rates (RTEWL) per cubic centimeter of $\mathrm{O}_{2}$ consumed during the last hour trials. In addition, we estimated the metabolic water production (MWP) of birds using the equivalence: $0.567 \mathrm{~mL} \mathrm{H}_{2} \mathrm{O}$ per liter $\mathrm{O}_{2}$ consumed (Schmidt-Nielsen 1997), and then the ratio between metabolic water production and water loss was calculated and tested for interspecific differences.

\section{RESULTS}

The Cinclodes species in our study exhibited variation in $\mathrm{m}_{\mathrm{b}}\left(\mathrm{F}_{2,16}=122.0 ; \mathrm{P}<0.001\right.$, Table 1), but TEWL did not show any species effect, despite the great differences in $\mathrm{m}_{\mathrm{b}}$ $\left(\mathrm{F}_{2,16}=2.53, \mathrm{P}<0.11\right)$. After correcting for body mass by dividing TEWL by body mass ${ }^{0.634}$, the exponent of the allometric equation found by Williams (1996), C. nigrofumosus had a significantly lower mass specific TEWL $\left(\mathrm{F}_{2,16}=3.74, \mathrm{P}=0.04\right)$ than $C$. fuscus and $C$. oustaleti, and no significant differences were found between the two species inhabiting primarily freshwater habitats (Table 1). Total evaporative water loss exhibited by each of the three Cinclodes was higher than expected by their respective $\mathrm{m}_{\mathrm{b}}(211 \%, 197 \%$ and 142 
$\%$ of allometrically expected TEWL; $\mathrm{t}_{7}=4.69$, $\mathrm{P}<0.01 ; \mathrm{t}_{5}=2.45, \mathrm{P}<0.02 ; \mathrm{t}_{4}=3.96, \mathrm{P}<$ 0.02 for $C$. nigrofumosus, $C$. oustaleti and $C$. fuscus, respectively). Linear regression analysis revealed a significant, positive relationship between TEWL and $\mathrm{TVO}_{2}(\mathrm{r}=$ $0.52 ; \mathrm{P}=0.02$, Fig. 1). Relative of evaporative water loss rates showed significant variation among Cinclodes species, and was higher in C. oustaleti and C. fuscus $\left(\mathrm{F}_{2,16}=4.12 ; \mathrm{P}=\right.$ 0.03 , Fig. 2). Accordingly, the ratio between metabolic water production and water loss was lower in $C$. nigrofumosus $\left(\mathrm{F}_{2,16}=3.71 ; \mathrm{P}=\right.$ 0.04, Fig. 3).

TABLE 1

Body mass, oxygen sonsumption and mass-specific total evaporative water loss (TEWL) measured at $25{ }^{\circ} \mathrm{C}$ of three Cinclodes species. Different superscript letters indicate significant differences following a Tukey test

Peso corporal, consumo de oxígeno y pérdida total de agua por evaporación masa-específico (TEWL) medida a $25^{\circ} \mathrm{C}$ de tres especies de Cinclodes. Diferentes superíndices indican diferencias significativas luego de un test de Tukey

\begin{tabular}{lccc}
\hline Variable & \multicolumn{3}{c}{ Species } \\
\cline { 2 - 4 } & C. nigrofumosus & C. oustaleti & C. fuscus \\
\hline Number of birds & 8 & 6 & 5 \\
Body mass $(\mathrm{g})$ & $67.8 \pm 8.4^{\mathrm{a}}$ & $24.9 \pm 1.3^{\mathrm{b}}$ & $28.9 \pm 1.4^{\mathrm{b}}$ \\
$\mathrm{VO}_{2}\left(\mathrm{~mL} \mathrm{O}_{2} \mathrm{~g}^{-1} \mathrm{~h}^{-1}\right)$ & $1.93 \pm 0.36^{\mathrm{a}}$ & $2.97 \pm 0.51^{\mathrm{a}}$ & $3.36 \pm 0.63^{\mathrm{b}}$ \\
TEWL $\left(\mathrm{mg} \mathrm{H}_{2} \mathrm{O} \mathrm{g}^{-0.63} \mathrm{~h}^{-1}\right)$ & $4.51 \pm 1.08^{\mathrm{a}}$ & $8.95 \pm 3.50^{\mathrm{b}}$ & $9.17 \pm 3.04^{\mathrm{b}}$ \\
\hline
\end{tabular}

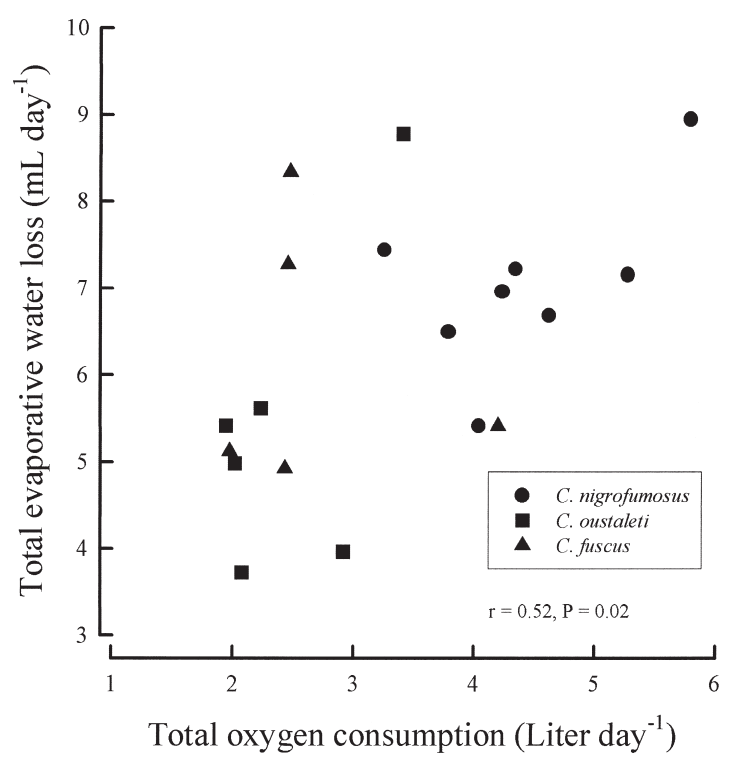

Fig. 1: Total evaporative water loss and total oxygen consumption in three species of Cinclodes. We found a significant, positive relationship between both variables (see text for details).

Pérdida total de agua por evaporación y consumo de oxígeno total en tres especies de Cinclodes. Se encontró una relación positiva y significativa entre ambas variables (ver texto para detalles).

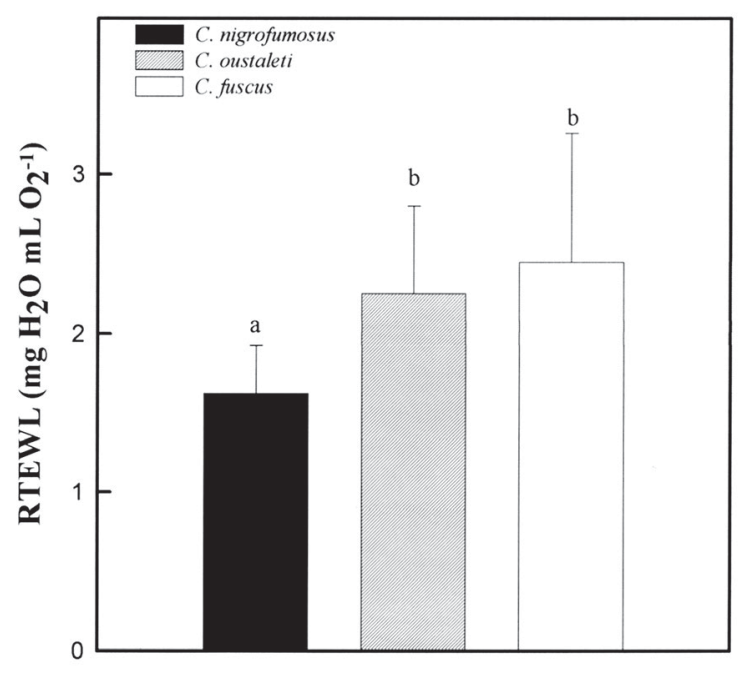

Fig. 2: Relative evaporative water loss (i.e., the ratio TEWL and oxygen consumption) in three species of Cinclodes at $25^{\circ} \mathrm{C}$. Significantly different means are indicated with different superscript letters $(\mathrm{P}<0.05)$.

Pérdida relativa de agua por evaporación (i.e., la razón entre TEWL y consumo de oxígeno) en tres especies de Cinclodes a $25{ }^{\circ} \mathrm{C}$. Promedios significativamente diferentes son indicados con diferentes superíndices $(\mathrm{P}<0,05)$. 


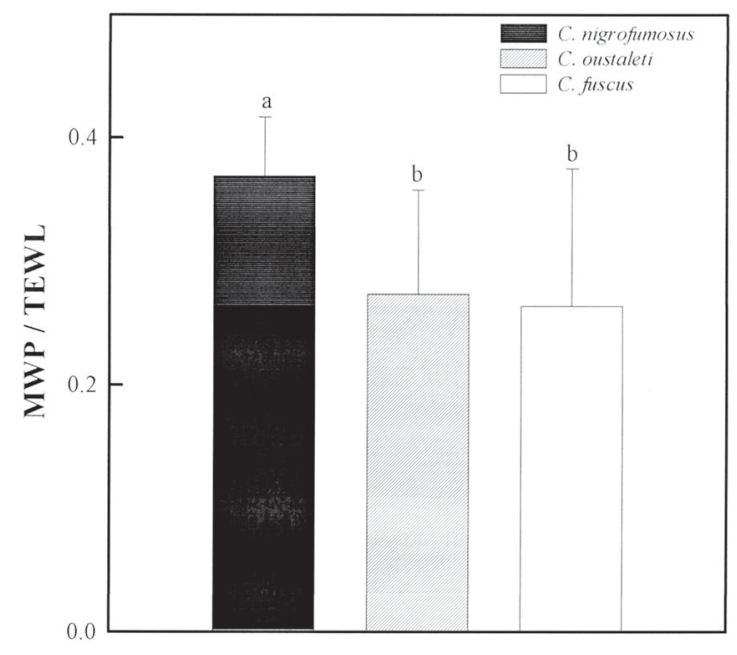

Fig. 3: The ratio of metabolic water production (MWP) to total evaporative water loss (TEWL) for the marine specialist species, C. nigrofumosus, and for generalist species, C. oustaleti and C. fuscus. Statistically different means are indicated with different letters $(\mathrm{P}<0.05)$. MWP was estimated using the equivalence: $0.567 \mathrm{~mL}$ $\mathrm{H}_{2} \mathrm{O}$ per liter $\mathrm{O}_{2}$ consumed (Schmidt-Nielsen 1997).

La razón entre la producción de agua metabólica (MWP) y la pérdida total de agua por evaporación (TEWL) para la especie especialista marina, C. nigrofumosus, y para las dos especies generalistas, C. oustaleti and C. fuscus. Promedios estadísticamente diferentes son indicados con diferentes letras $(\mathrm{P}<0,05)$. MWP fue estimada utilizando la equivalencia: $0,567 \mathrm{~mL} \mathrm{H}_{2} \mathrm{O}$ por litro de $\mathrm{O}_{2}$ consumido (Schmidt-Nielsen 1997).

\section{DISCUSSION}

The marine dwelling species, C. nigrofumosus, had, on a mass-specific basis, a lower TEWL than the two limnic species. Since both dietary habits (i.e., carnivorous), and main climate conditions (e.g., rainfall and mean temperatures) are similar in the three studied species (di Castri \& Hajek 1976), the observed differences in mass-specific TEWL may be attributed to differential habitat use. The lower TEWL found in C. nigrofumosus is likely a consequence of exploitation of salt-loaded prey with high osmotic loads, which, in turn, may impose the need for water conservation. The genus Cinclodes includes 12 recognized species (Sibley \& Monroe 1990). Although all Cinclodes species inhabit the land-water boundary (streams, meadows, and beaches), there is considerable interspecific (and probably intraspecific) variation in their use of coastal environments (Sabat et al. 2003 and references there). A molecular phylogenetic hypothesis of the relationships of Cinclodes suggests that the marine specialist condition have been derived twice in Cinclodes, once in the C. nigrofumosus/C. taczanowskii group and once in $C$. antarcticus from an non-marine acentrus ( $T$. Chesser unpublished data). The marine condition in Cinclodes seems to be an apomorphic condition, whereas the life in limnic habitats is the plesiomorphic condition. In this sense, the fact that TEWL of all Cinclodes species are above the values predicted from $m_{b}$, was not surprising considering that Cinclodes speciation probably occurred from fresh-water dwelling species. However, C. nigrofumosus exhibited lower mass-specific TEWL than the other fresh-water species, which may allow this species to cope with water stress. On the other hand, due to the fact that TEWL depends on the contribution of the respiratory water loss, which in turns, depends on the levels of energy expenditure (Fig. 1), seems to be appropriate to compare the ratio between the TEWL and oxygen consumption (i.e., RTEWL), as an index of water recovery efficiency (Williams 1996). Indeed, C. nigrofumosus presents lower RTEWL than both $C$. oustaleti and C. fuscus, (Fig. 2) which results in an average reduction in water loss by $\mathrm{O}_{2}$-consumption of $30 \%$. Values of RTEWL for $C$. nigrofumosus appear to be within the range reported for passerines of similar $\mathrm{m}_{\mathrm{b}}$, but were higher in the case of $C$. oustaleti and C. fuscus (Williams 1996). Additionally, water balance seemed more efficient in the marine species, $C$. nigrofumosus. Metabolic water production in this marine species was up to $37 \%$ of water loss, while in $C$. oustaleti and $C$. fuscus this value was only of $27 \%$ and $25 \%$, respectively (Fig. 3). Again, values of metabolic water production by $C$. nigrofumosus were within the range expected for its $\mathrm{m}_{\mathrm{b}}$, but the freshwater species (C. oustaleti and C. fuscus) presented significantly lower values. This indicates that total water requirements (pre-formed water in food and from freshwater drinking) are lower in the marine species. The mechanism that has evolved in $C$. nigrofumosus to reduce massspecific TEWL remains to be tested. Several studies have reported that the morphology of the nasal passages in birds can contribute to a decrease in evaporative water loss through a countercurrent heat exchange mechanism present in the turbinates (Geist 2000). Haugen et al. (2003) demonstrated that adjustments in ratios of lipids in the skin are associated with changes in cutaneous water loss in hoopoe larks (Alaemon alaudipes) from the Arabian Desert. 
Hence, further studies are needed to test if Cinclodes exhibits differences in the function of the nasal cavity and skin permeability, and to determine the relative contribution of respiratory and cutaneous water loss to TEWL in Cinclodes.

Our study indicates that within the genus Cinclodes, the marine dwelling species has reduced levels of mass-specific TEWL. Current phylogenetic considerations suggest that the physiological traits involved in water conservation in Cinclodes nigrofumosus should be seen as a novel adaptation to saline and often dry habitats. In addition, physiological adjustments to climate conditions may be the result of phenotypic plasticity (the modification of phenotype according to environmental cues; see Pigliucci 2001, Hammond et al. 2001). Since physiological and morphological features related to water economy in birds may be modified by the acclimation process (i.e., it exhibits phenotypic flexibility; see Williams \& Tieleman 2000, Haugen et al. 2003, Tieleman et al. 2003), it is likely that Cinclodes species modify their physiology in order to adapt to different levels of dehydration and salt-loads. This experiment remains to be done, and should include chronic diet acclimation (i.e., weeks or months), with varying salt loads, and measurements of TEWL both before and after diet treatments, in individuals of Cinclodes species.

\section{ACKNOWLEDGEMENTS}

This study was funded by FONDECYT grant № 1010647 to PS and FONDAP 1501-0001 (Program 1 to FB). Terry Chesser allows us the reconstruction of the evolution of marine specialization in the genus. Joseph Williams and Luis Ebensperger provided useful comments.

\section{LITERATURE CITED}

BRAUN E (1978) Renal response of the starling (Sturnus vulgaris) to an intravenous salt load. American Journal of Physiology 234: F270-F278.

DAWSON WR (1982) Evaporative losses of water by birds. Comparative Biochemistry and Physiology 71: 495-509.

DI CASTRI F \& E HAJEK (1976) Bioclimatología de Chile. Editorial Universidad Católica, Santiago, Chile. $128 \mathrm{pp}$.

GARLAND T Jr \& SC ADOLPH (1994) Why not do twospecies comparative studies: limitations on inferring adaptation. Physiological Zoology 67: 797-828.
GARLAND T Jr, PE MIDFORD \& AR IVES (1999) An introduction to phylogenetically based statistical methods, with a new method for confidence intervals on ancestral values. American Zoologist 39: $374-388$.

GEIST NR (2000) Nasal turbinate function in birds. Physiological and Biochemical Physiology 73: 581589.

GOLDSTEIN DL, JB WILLIAMS \& EJ BRAUN (1990) Osmoregulation in the field by salt-marsh Savannah sparrows Passerculus sandwichensis beldingi. Physiological Zoology 63: 669-682.

HAINSWORTH FR (1968) Evaporative water loss from rats in the heat. American Journal of Physiology 214: 979-982.

HAMMOND KA, J SZEWCZAK \& E KROL (2001) Effects of altitude on organ phenotypic plasticity along an altitudinal gradient. Journal of Experimental Biology 204: 1991-2000.

HAUGEN MJ, BE TIELEMAN \& JB WILLIAMS (2003) Phenotypic flexibility in cutaneous water loss and lipids of the stratum corneum. Journal of Experimental Biology 206: 3581-3588.

HOLMES WN \& JG PHILLIPS (1985) The avian salt gland. Biological Reviews 60: 213-256.

JORGE R, E TABILO-VALDIVIESO \& V MONDACA (1998) Avifauna de la bahía de Coquimbo, Chile. Boletín Chileno de Ornitología (Chile) 5: 2-9.

MCNAB BK (2002) The physiological ecology of vertebrates. Cornell University Press, New York, New York, USA. 576 pp.

PIGLIUCCI M (2001) Phenotypic plasticity. The Johns Hopkins University Press, Baltimore, Maryland, USA. 328 pp.

POULSON TL \& GA BARTHOLOMEW (1962) Salt balance in the savannah sparrow. Physiological Zoology 35: 109-119.

SABAT P (2000) Birds in marine and saline environments: living in dry habitat. Revista Chilena de Historia Natural 73: 401-410.

SABAT P \& C MARTÍNEZ DEL RÍO (2002) Inter and intraspecific variation in the use of marine food resources by three Cinclodes (Furnariidae, Aves) species: carbon isotopes and osmoregulatory physiology. Zoology 105: 247-256.

SABAT P, JM FARIÑA \& M SOTO-GAMBOA (2003) Terrestrial birds living on marine environments: does dietary composition of Cinclodes nigrofumosus (Passeriformes: Furnariidae) predict their osmotic load? Revista Chilena de Historia Natural 76: 335-343.

SIELFELD W, N AMADO, J HERREROS, R PEREDO \& A REBOLLEDO (1996) La avifauna del salar de Huasco: I Región, Chile. Boletín Chileno de Ornitología (Chile) 3: 17-24.

SCHMIDT-NIELSEN K (1997) Animal physiology. Cambridge University Press. New York, New York, USA. 612 pp.

SIBLEY CG \& B MONROE (1990) Distribution and taxonomy of birds of the world. Yale University Press, New Haven, Connecticut, USA. 1111 pp.

STOTZ DF, JW SITTZPATRICK, TA PARKER III \& DK MOSKOVITZ (1996) Neotropical birds ecology and conservation. The University of Chicago Press, Chicago, Illinois, USA. 496 pp.

TIELEMAN BR, JB WILLIAMS, G MICHAELI \& B PINSHOW (1999) The role of the nasal passages in the water economy of crested larks and desert larks. Physiological and Biochemical Zoology 72: 219226. 
TIELEMAN BI, JB WILLIAMS \& MB BUSCHUR (2002) Physiological adjustments to arid and mesic environments in larks (Alaudidae) Physiological and Biochemical Zoology 75: 305-313.

TIELEMAN BI, JB WILLIAMS \& MB BUSCHUR \& K BROWN (2003) Phenotypic variation of larks along an aridity gradient: are desert birds more flexible? Ecology 84: 1800-1815.

WILLIAMS JB (1996) A phylogenetic perspective of evaporative water loss in birds. Auk 113: 457-472.

Associate Editor: Luis Ebensperger

Received November 4, 2003; accepted December 16, 2003
WILLIAMS JB \& BI TIELEMAN (2000) Flexibility in basal metabolic rate and evaporative water loss among hoopoe larks exposed to different environmental temperatures. Journal of Experimental Biology 203: 3153-3259.

WITHERS PC (1977) Measurements of metabolic rate, $\mathrm{VCO}_{2}$, and evaporative water loss with flow through mask. Journal of Applied Physiology 42: 120-123. 